\title{
CONTEXTUAL EFFECT OF PUSKESMAS ON ANXIETY AMONG PREGNANT WOMEN IN KUTAI KARTANEGARA REGENCY, EAST KALIMANTAN
}

\author{
Imelda Dearni Simarmata), Uki Retno Budihastuti²), Didik Tamtomo3) \\ 1) Masters Program in Public Health, Universitas Sebelas Maret \\ ${ }^{2)}$ Department of Obstetrics and Gynecology, Dr. Moewardi Hospital \\ 3)Faculty of Medicine, Universitas Sebelas Maret
}

\begin{abstract}
Background: Depressive and anxiety disorders during pregnancy can have detrimental effects on the course of the pregnancy, its outcome, the development of a child and maternal well-being. Contextual effect of community health center (puskesmas) on anxiety among pregnant women has been little studied. The purpose of this study was to examine contextual effect of puskesmas on anxiety among pregnant women in Kutai Kartanegara Regency, East Kalimantan.

Subjects and Method: A cross-sectional study was carried out at 25 puskesmas in Kutai Kartanegara, East Kalimantan, Indonesia, from November to December 2018. A sample of 200 pregnant women was selected by simple random sampling. The dependent variable was anxiety. The independent variables were education, parity, employment status, stress, family income, social interaction, family support, and counselling. The data were collected by questionnaire and analyzed by a multilevel regression.

Results: Anxiety reduced with high education $(\mathrm{b}=-2.38 ; 95 \% \mathrm{CI}=-3.90$ to $-0.87 ; \mathrm{p}=$ 0.002), high family income $(b=-4.63 ; 95 \% \mathrm{CI}=-7.66$ to $-1.60 ; \mathrm{p}=0.003)$, parity $(\mathrm{b}=-$ $1.55 ; 95 \% \mathrm{CI}=-2.87$ to $-0.23 ; \mathrm{p}=0.022)$, strong family support $(\mathrm{b}=-0.37 ; 95 \% \mathrm{CI}=-0.51$ to $-0.23 ; \mathrm{p}=0.001)$, stress $(\mathrm{b}=0.32 ; 95 \% \mathrm{CI}=0.15$ to $0.49 ; \mathrm{p}=0.001)$, strong social interaction $(\mathrm{b}=-0.25 ; 95 \% \mathrm{CI}=-0.39$ to $-0.11 ; \mathrm{p}=0.001)$, and counselling $(\mathrm{b}=-0.94 ; 95 \%$ $\mathrm{CI}=-1.78$ to $-0.1 ; \mathrm{p}=0.028)$. Puskesmas had negligible contextual effect on anxiety with $\mathrm{ICC}=3.9 \%$.

Conclusion: Anxiety reduces with high education, high family income, parity, strong family support, stress, strong social interaction, and counselling. Puskesmas has negligible contextual effect on anxiety.
\end{abstract}

Keywords: anxiety, pregnant women, community health center, multilevel analysis

\section{Correspondence:}

Imelda Dearni Simarmata. Masters Program in Public Health, Universitas Sebelas Maret. Jl. Ir. Sutami 36A, Surakarta 57126, Central Java, Indonesia.

Email: imeldadearni1888@gmail.com. Mobile: 081227657035

The 5th International Conference on Public Health Best Western Premier Hotel, Solo, Indonesia, February 13-14, 2019 | 288

https://doi.org/10.26911/theicph.2019.03.34 